\title{
THE INFLUENCE OF SAVOIR-VIVRE ON THE QUALITY OF SERVICES IN THE HOTEL BUSINESS TESTED USING THE AHP METHOD
}

\author{
Maciej Abram, Katarzyna Janik, Michal Kovačic, Bartłomiej Walas
}

\begin{abstract}
The main objective of the study was to examine what features of hotel employees the guests pay the most attention to. Is the hotel standard more important that the behaviour and attitude of its personnel? In order to check this, the surveys among tourists were carried out. The part concerning aspects of savoir-vivre and quality was examined using the AHP method. The Analytic Hierarchy Process (AHP) is one of the most famous mathematical methods solving multi-criteria decision-making problems in the world. On the basis of the results, it can be observed what factors are more important for the respondents, in this case for the tourists - hotel guests. In the further development of research carried out using the AHP method, alternative models of personnel can be created in order to facilitate building a group of workers with ideal characteristics, and to know what needs to be improved so that the quality of services is higher, and so that the hotel can enjoy popularity and therefore higher profits.
\end{abstract}

Keywords: Savoir-vivre, AHP, quality of service, hospitality business, hotel service

\section{Introduction}

The expression savoir-vivre is derived from French and means the art of life. It means the knowledge of customs and forms of socializing, courtesy rules, the ability to act in life and to cope with variety of difficult situations. It is worth mentioning that savoir-vivre is a culturally conditioned phenomenon, and therefore it is significantly different depending on the region of the world.

Generally, the rules of savoir-vivre are: smile, kindness, punctuality, discretion, loyalty, politeness (Kopaliński, 1999).

Savoir-vivre primarily affects several major areas of life (Sawicka, 2011): the table ceremonial manners, appearance and proper outfit; forms of socializing, communication and behaviour in specific situations. It is also mandatory knowledge necessary in certain professions. Savoir-vivre is particularly associated with a hotel as a place where everything is perfectly prepared, and each employee knows how to behave in a particular situation, so that the guests feel satisfied and willing to visit the hotel again. 
There are currently two trends. The first is the trend to carry out trainings and courses on manners and good image (Kalman a kol., 2007). International hotel chains employ professionals who conduct such trainings for the personnel. Employers, apart from qualifications, also pay attention to the personal culture and social manners (Borkowski, Čief, 2015). All this in order to take care of the proper image of a company, which increasingly affects higher sales. In the past several years, a field of business ethics has developed. Some universities treat it as an independent subject. The second distinctive trend is the utter lack of knowledge of the basic principles of savoir-vivre. Some people do not see conceptual differences between the etiquette and ethics, not to mention the lack of knowledge of the basic principles of social manners. Therefore, the tourists opinion gathered on the basis of research and concerning the meaning of the etiquette with regard to the quality of the services provided in the hotel business is an important issue.

To truly understand the concept of hospitality services, one must first answer the question of what exactly the service itself is. In the discipline's literature there are many different definitions of a service. It is well defined by Daszkowska, who considers a service a useful product with of a intangible character, produced by human labour in the production process, which is supposed to affect a specific object, for example a human being, or to satisfy human needs (Daszkowska, 1998). Once the image of a service itself has been formed, the second part of the name i.e. hotel, needs to be taken into consideration. Such service consists of many actions related to satisfying the basic needs of living, for example: accommodation, food and entertainment (Panasiuk, 2009). A hotel service is characteristic mainly due to unity of production and consumption space, complementarity, constant potential, impermanence and instantaneity, high labouroutput ratio, capital intensity and complexity (Borowski, Nižňanský, 2015). It is important to note that the hotel service is characterised by the fact that the moment of consumption is inextricably linked to the moment of its manufacture. What's also important is the appearance of the hotel and personnel whose behaviour and knowledge are always assessed by guests. This element may decisive of whether the guest will be happy with the service offered, will their needs be satisfied, and finally, whether they will use the hotel services again (Borkowski, 2007).

Decisions are an important and inherent element in human life. They may be made by an individual or by a group. Decision-making entails many consequences, for example, it can an impact on the quality of work. It is important that these actions are taken with awareness, with a specific goal in mind and are not forced by anybody. The emergence of opportunities when making the decision overweighs one of the alternatives. Each problem entails such a decision for which it can be concluded that there is no other, better option. The problem arises when one has to choose such an alternative that will cover the complete collection of the defined goals (Adamus, Greda, 2005). As it is easy to guess, the selected alternative is the one that has the most preferences. In this case, there are two 
options for arrangement, namely according to the quality or quantity. In the first case, it is specified whether the particular variant is greater than the others with regard to the given criterion. However, the second criterion is providing information, how much better the particular possibility is than the other one. This consideration implies only one decision-making person. However, it is rarely so that a person about to make a decision does not consult it with others. Usually this occurs when important matters are at stake. Such moments create a problem when the aspirations and the assessed variant have different values for decision makers. Incorporation of different values into a single system of preferences leads to the creation of real conflict. It is so because the structure is not hierarchical i.e. the objective principles taking into account positions do not appear. Organizing different variants by a group of people based on their own assessment of the members of the group, mainly on the basis of individual variant organization is a basic method in a theory of group decision making (Findeisen, 1985).

While solving multi-criteria problems by a group it usually comes down to a single criterion summing up all the consequences of the problem which is the socalled single-criterion analysis. Unfortunately, this method, although easy to apply, is not entirely reliable. It is usually used in less complex cases. Making more important decisions requires more preparation, hence the assessment of variants in relation to various criteria is in this case justified. In his book, Kasprzak states the elements that need to be taken into account when analysing the issue (Kasprzak, 1992). Firstly, the set of criteria should present all the important attributes of the establishment being subject to decision analysis, the selection of criteria should be guided by the possibilities of their use in decision analyses. However, introducing data should be done with a view to reducing excessive amounts of sub-criteria, their aggregation, but in such a way that their decomposition is always possible that would facilitate the process of analysis of the complex decision-making situations (it is assumed that, in practice, the number of criteria should not exceed $n$ $=10$ ) and it needs to be remembered not to repeat the criteria in order to avoid double assessment from the same point of view (Kasprzak, 1992). When deciding on variants which are described as partial elements, there is a problem of choosing the best one possible in every respect, however these situations are rare. The one that prevail are such where variants are in some ways better and in some ways worse than the others. A good choice would be to find the variant which is most satisfactory, the one that will be the best possible, however this does not mean that it will be perfect.

AHP (Analytic Hierarchy Process) and ANP (Analytic Network Process) used in many countries are considered the best methods (Adamus, Greda, 2005). This paper uses a multi-criteria tool of Analytic Hierarchy Process. This method makes it possible to analytically solve the problem and decide among many possible criteria. AHP is one of the fastest growing methods relating to multicriteria problem solving. 
The AHP and ANP creator is Prof. Thomas L. Saaty - a mathematician at the American University of Pittsburgh, who already in the 1970s. began studying both methods. Prof. Saaty published a book on the ANP method entitled "Decision Making with Dependence and Feedback. The Analytic Network Process". A computer programme developed by R. Saaty and W. Adams - Super Decisions ${ }^{\odot}$ is a practical component allowing to make even more difficult decisions. In addition for the AHP method, a computer program Expert Choice was created which significantly facilitates calculations.

To better understand the pattern of conduct while using the AHP method, the order of proceeding was enumerated below (Adamus, Greda, 2005):

1. Defining the problem.

2. Specifying the main purpose.

3. Creating the structure of the problem in the form of a hierarchical model i.e. setting the criteria and sub-criteria of the main purpose.

4. Determination of the dominance of the major criteria by comparing in pairs their importance in achieving the main goal.

5. Determination of the dominance of sub-criteria by comparing in pairs their importance in achieving the main goal.

6. Writing down decision variants meeting the sub-criteria and criteria of the main purpose.

7. Defining preferences of the developed variants by comparing in pairs their importance in the implementation of each sub-criterion.

8. Presenting verbal feedback by using the numbers in a Saaty's fundamental preference scale (at each hierarchical level, the opinion may be provided by another expert or group of experts).

9. Using these numbers to determine the priorities of "hierarchical tree" elements in relation to their impact on the main objective.

10. Synthesis of the results obtained - choosing the best variant (with the highest priority value) which will, to the greatest extent, contribute to the achievement of the goal.

The result of all the comparisons is a model constructed using the quotient scale. Such a model is called a priority additive function. Alternative decision, which corresponds to the highest total value of priority function, is considered to be the best and most recommended for use in practice (Adamus, Szara, 2000). In the AHP method, it is recommended to limit the number of elements being compared at each level of the hierarchical tree to $7(+/-) 2$. The presented restriction can be eliminated in the AHP model by introducing problem criteria, its sub-criteria and sub-sub criteria, etc. As far as complex problems are concerned, there is the possibility of combining the criteria in groups and those in sub-groups, etc., so there is the opportunity to compare a few thousand items. The AHP and ANP methods introduce measurement of discrepancies in comparisons in the form of a compliance index C.I. or a compliance rate C.R. In the theory of ANP/AHP 
perfect compatibility (consequence) in the opinions $($ C.I. $=0)$ is not required. The C.R. value of $10 \%$ is considered acceptable. It is worth noting that low inconsistency is necessary, but not sufficient to make the right decision. The compatibility may be perfect, but the decision can be wrong anyway. In this case, logical thinking is more important (Adamus, Szara, 2000). Summing up the above, the problem is presented in the form of a multi-level hierarchical structure whose levels are arranged with decreasing importance. The element on each of the hierarchical levels are compared in pairs.

The main problem of AHP is measuring the uncountable factors. To measure the uncountable criteria and goals, so far such opinions have been expressed in the verbal form and they should be present in the form of numbers, one can use e.g. Saaty's comparison scale (table 1).

Table 1: Saaty's fundamental scale of comparisons

\begin{tabular}{|c|c|c|}
\hline $\begin{array}{l}\text { The scale of } \\
\text { importance }\end{array}$ & Definition & Explanation \\
\hline 1 & Equal importance & The equivalence of the two compared items \\
\hline 3 & $\begin{array}{r}\text { Weak or moderate } \\
\text { advantage }\end{array}$ & $\begin{array}{r}\begin{array}{r}\text { Small importance or preference of one element } \\
\text { over another }\end{array} \\
\end{array}$ \\
\hline 5 & Strong advantage & Strong preference of one element over another \\
\hline 7 & $\begin{array}{r}\text { A very strong } \\
\text { advantage }\end{array}$ & $\begin{array}{r}\text { The predominant importance of one element over } \\
\text { another }\end{array}$ \\
\hline 9 & $\begin{array}{r}\text { Absolute or } \\
\text { extreme }\end{array}$ & $\begin{array}{r}\text { Absolutely higher importance of one element over } \\
\text { another }\end{array}$ \\
\hline $2,4,6,8$ & $\begin{array}{r}\text { For compromising } \\
\text { comparisons } \\
\text { between the above } \\
\text { values }\end{array}$ & $\begin{array}{l}\text { Sometimes there is a need for numerical } \\
\text { interpolation of compromising opinions as there is } \\
\text { no proper word to describe them. }\end{array}$ \\
\hline $1,1-1,9$ & $\begin{array}{r}\text { For items of } \\
\text { similar meaning }\end{array}$ & $\begin{array}{l}\text { If the meaning of the items is close and they are } \\
\text { almost indistinguishable, the average of } 1.3 \text { is } \\
\text { assumed and the extreme equals } 1.9\end{array}$ \\
\hline $\begin{array}{l}\text { The inverse of } \\
\text { the above } \\
\text { scales }\end{array}$ & $\begin{array}{r}\text { Transitivity of } \\
\text { evaluations }\end{array}$ & $\begin{array}{l}\text { If element "o" is assigned one of the above non- } \\
\text { zero numbers that represents the result of a } \\
\text { comparison with " } \mathrm{k} \text { " element, then "k" is the } \\
\text { inverse value when we compare it with "o". If the } \\
\text { comparison of } \mathrm{X} \text { and } \mathrm{Y} \text { is assigned value "a", then } \\
\text { we automatically need to assume that the result of } \\
\text { the comparison of } \mathrm{X} \text { and } \mathrm{Y} \text { " } 1 / \mathrm{a} \text { " }\end{array}$ \\
\hline
\end{tabular}

Source: Own elaboration on the basis of Saaty (2001).

This paper uses a nine-level Saaty's preference scale that enables to include the knowledge and experience of the decision maker and allows to indicate how many times one element prevails over another in reference to a given criterion. A person can express their preferences between each pair of elements, first in words 
as: equal importance, poor advantage, a strong advantage, a very strong advantage and absolutely a strong advantage. Then these opinions shall be recorded in the form of numbers as 1, 3, 5, 7, 9. The intermediary numbers: 2, 4, 6, 8, are also introduced and used when it's difficult to express our opinions or feelings. The number of 4 for example points over poor advantage of one item over another. Hence, by making comparisons, we have a choice of seventeen possible values which were presented in.

In the AHP method, reversible comparisons in pairs are conducted, where $a_{i, j=1 / a j, i}$ and $a_{i, i}=1$. This gives better and more accurate results than direct indication of a solution. Specific opinions are placed in a so-called square matrix of comparison in pairs $(n \times n) A=\left[a_{i, j}\right]$. It presents the evaluation showing the advantage of the items on the left side of the matrix over the items on its top. This matrix is used to create $n(n-1) / 2$ of comparisons in pairs. The number of these comparisons stems from the fact that on the diagonal of the matrix of "n" elements there are " $n "$ ones, and half of the opinions are inverse. The matrices of comparisons in pairs are constructed for the elements placed on each level of the hierarchical structure. Therefore, in the hierarchy, the first thing is to build the matrix to determine the degree of importance of the criteria in relation to the defined top purpose. Next are the matrices, which indicate the degree of importance of adopted decision variants in relation to each sub-criteria placed on a directly higher level. An example of a square matrix comparing the size of three apples $\mathrm{A}, \mathrm{B}$ and $\mathrm{C}$ is presented in Figure 1 . Assuming that apple $\mathrm{A}$ is twice as big as Apple B and six times as big as Apple C, then Apple B is $1 / 2$ the size of Apple A, and Apple $\mathrm{C}$ is $-1 / 6$ the size of Apple A.

Figure 1: A square matrix of comparisons in pairs for apples

\begin{tabular}{|c|c|c|c|c|c|}
\hline \multirow[t]{2}{*}{$\begin{array}{l}\text { A comparison of } \\
\text { the size of apples }\end{array}$} & $\begin{array}{c}\text { Apple } \\
\text { A }\end{array}$ & $\begin{array}{c}\text { Apple } \\
\text { B }\end{array}$ & $\underset{\text { C }}{\text { Apple }}$ & \multirow{2}{*}{$\begin{array}{l}\text { The relative } \\
\text { size of apples } \\
\text { calculated } \\
\text { based on the } \\
\text { standardizatio } \\
\text { n of the } \\
\text { selected } \\
\text { column } \\
\end{array}$} & \multirow[b]{2}{*}{ Priorities } \\
\hline & & & & & \\
\hline Apple A & 1 & 2 & 6 & $6 / 10$ & A \\
\hline Apple B & $1 / 2$ & 1 & 3 & $3 / 10$ & B \\
\hline Apple C & $1 / 6$ & $1 / 3$ & 1 & $1 / 10$ & $\mathrm{C}$ \\
\hline
\end{tabular}

Source: Saaty, 2004a 


\section{Material and research method}

The AHP method was used to assess the importance of the elements of savoir-vivre in the hotel business. The appropriate evaluation criteria have been selected i.e.: staff competencies, personnel's appearance, individual approach to guests, staff's knowledge of the etiquette, employees' personality, kindness staff employees, proper way of laying the table and serving food, the high quality of services and the hotel's standard. The study was conducted at the turn of February and March 2013, at Krakow's Market Square near Florianska Gate, the underpass and the St. Mary's Church. A survey was conducted among 120 people, including 50 foreigners. The survey was composed of three parts - the first one consisted of 7 questions about general travel preferences and the hotel choices. The second part was a table with comparison of criteria that a tourist had to choose and select their intensity, i.e. which criterion is more important to them. The third part was respondent's particulars i.e. basic and important questions about the respondent.

\section{Test results - the impact of staff's savoir-vivre knowledge on the quality of service}

Graph 1: Criteria priorities

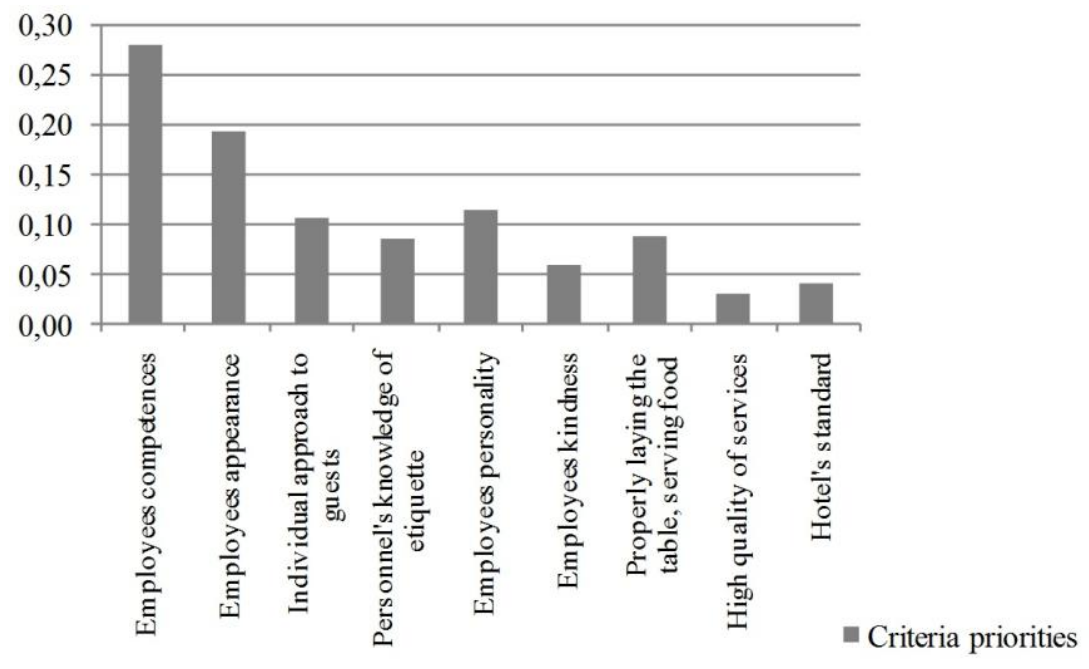

The AHP method was used to assess the importance of the elements of savoir-vivre in the hotel business. The appropriate evaluation criteria have been selected i.e.: staff competencies, personnel's appearance, individual approach to 
guests, staff's knowledge of the etiquette, employees' personality, kindness staff employees, proper way of laying the table and serving food, the high quality of services and the hotel's standard.

When a group $f$ individuals wishes to make a collective choice, then each person of the group can determine their individual preferences. Based on that, using the geometric mean, a combination of individual opinions in one group choice was created. In this study, each of the tourists was supposed to compare the criteria specified in pairs using Saaty's fundamental scale of comparisons i.e. from 1 to 9 , and respond to a question: Which criterion is more important and what is the advantage of this element over the others?

\section{Discussion and conclusion}

The results of the study indicate that the most important criteria are staff competencies, appearance, personality and individual employee employees approach to a guest.

The results of the survey presented show that tourists increasingly pay attention to the quality of service understood as the knowledge of principles of savoir-vivre, and not as the hotel's standard or design. This may be influenced by better knowledge of the hotel rating requirements, so selecting a hotel with a specific number of stars, they know what to expect when it comes to the hotel's standard or what is the range of additional services. After arriving to a hotel, they evaluate the staff, observe their behaviour in different situations, they sense the type of atmosphere among the staff and how they are served. Thus, they form the opinion about the hotel and this also has an impact on the assessment of the quality of services. Guests often see the smallest details such as the placement of tableware, the receptionist's smile, or simple favours and kindness of the personnel. Tourists love to be noticed, recognized by the staff, they like to feel important, which satisfies their certain needs, and thus allows the acquisition of a permanent hotel customer. Therefore, the hotels care about good relationships with guests by sending them holiday wishes, giving discounts or loyalty cards, and sometimes small gifts that are much appreciated by the guests and are make it more likely for the customer to return to the hotel. Most of the responses indicated that the guests were choosing hotels guided by their own or their friends' experience, and coming back to the particular location, they usually chose the same establishment. Tourists pay attention to professionalism, staff's competences, therefore the owners or managers of hotels should take care of regularly reminding the staff about hotel rules and organizing trainings in savoir-vivre. In larger facilities, a good idea would be to create a book with he standards relating to the appropriate work uniform or behaviour but it would also systematise the working technique on a particular position which will prevent making mistakes, and thus increase the quality of service. 


\section{References}

ADAMUS, W. - SZARA, K. 2000. Zastosowanie Analitycznego Procesu Hierarchicznego AHP do racjonalizacji zarządzania i organizacji gospodarstw (przedsiębiorstw). In Zagadnienia Ekonomiki Rolnej. no 4-5, 2000, pp. 20.

ADAMUS, W. - GREDA, A. 2005. Wielokryterialne wspomaganie decyzji w rozwiązywaniu problemów organizacyjnych i menedżerskich. In Badania Operacyjne i decyzyjne. no. 2, 2005, pp. 5-36.

BORKOWSKI, S. 2007. Jakość i efektywność ustug hotelarskich. Warszawa : PWN, 2007. pp. 31-37.

BORKOWSKI, K. - ČIEF, R. 2015. Vybrané možnosti hodnotenia vybavenosti službami cestovného ruchu. In Ekologické štúdie. 2015, roč. 6, č. 2, s. 91-101.

BORKOWSKI, K. - NIŽNANSKÝ, B. 2015. Oblast' ako produkt cestovného ruchu v subjektívnom hodnotení jej návštevníkov a obyvatel'ov. In Ekologické štúdie. 2015, roč. 6, č. 2, s. 82-90.

DASZOWSKA, M. 1998. Ustugi. Produkcja, rynek, marketing. Warszawa : WN PWN, 1998, p. 17.

FINDEISEN, W. 1985. Analiza systemowa - Podstawy i Metodologia. Warszawa : PWN, 1985, $670 \mathrm{p}$.

KALMAN, M. - DOHNAL, T. - KOTULÁK, Z. - PAVELKA, J. - HAMŘÍK, Z. - OSVALDOVÁ, M. - BÖHM, H. 2007. Národni a regionální politiky a strategické dokumenty v oblasti cestovního ruchu. Praha, 2007, s. 103.

KASPRZAK, T. 1992. Systemy wspomagania decyzji wielokryterialnych. Warszawa : Wyd. Uniwersytetu Warszawskiego, 1992. p. 31.

KOPALIŇSKI, W. 1999. Stownik wyrazów obcych i zwrotów obcojęzycznych. Warszawa : MUZA SA, 1999. 448 p.

PANASIUK, A. 2009. Hotelarstwo. Warszawa : WNPWN, 2009. p. 24.

SAATY, T. L. 2001. Decision Making for Leaders. The Analytic Hierarchy Process for Decisions In a Complex World. Pittsburgh : RWS Publications.

SAATY, T. L. 2004a. Decision Making - The Analytic Hierarchy and Network Processes (AHP/ANP). In Journal of Systems Science and Systems Engineering. vol. 13, no. 1, pp. 1-34.

SAATY, T. L. 2004b. Priorities Originate from Dominance and Order Topology in AHP/ANP; The Fundamental Scale, Relative Scales and When to Preserve Rank. Jagiellonian University.

SAWICKA, E. 2011. Savoir-vivre podręcznik dobrych manier. Warszawa-BielskoBiała : Park, 2011, pp. 13-23.

http://www.kns.b2me.pl/art-iso-systemy-zarzadzania-jakoscia,13,0.html

\section{Dr. Maciej Abram}

Akademia Wychowania Fizycznego im. Bronisława Czecha w Krakowie 


\section{Bc. Katarzyna Janik}

Akademia Wychowania Fizycznego im. Bronisława Czecha w Krakowie

PaedDr. Michal Kovačic, PhD.

Faculty of Education, Catholic University

Hrabovská cesta 1, 03401 Ružomberok

Dr. Bartlomiej Walas

Wyższa Szkoła Turystyki i Ekologii

Ul. Zamkowa 1, 34-200 Sucha Beskidzka, Polska 